\title{
Discourse and Heterogeneity: Situating Orientalism
}

\begin{abstract}
Par la diversité de son humeur, tour à tour mystique ou joyeuse, babillarde, taciturne, emportée, nonchalante, elle allait rappelant en lui mille désirs, évoquant des instincts ou des réminiscences. Elle était l'amoureuse de tous les romans, l'héroine de tous les drames, le vague elle de tous les volumes de vers. Il retrouvait sur ses épaules la couleur ambrée de l'odalisque au bain; elle avait le corsage long de châtelaines féodales; elle ressemblait aussi à la Femme pâle de Barcelone, mais elle était par-dessus tout Ange!
\end{abstract}

[According to her changing moods, in turn meditative or gay, talkative, silent, passionate, and nonchalant, she awakened in him a thousand desires, called up instincts or memories. She was the beloved mistress of all the novels, the heroine of all the dramas, the vague "she" of all the volumes of verse. On her shoulders, he rediscovered the amber color of Ingres's Odalisque au bain; her waist was long like the feudal chatelaines; she resembled the "Femme Pâle de Barcelone," but above all, she was a complete Angel.]

Flaubert, Madame Bovary (1857)

In Flaubert's Madame Bovary, a novel reflecting the tedium and homogeneity of French provincial life, Emma's young lover Léon imagines that he finds on her shoulders "the amber color of the Odalisque au bain." The workings of masculine desire are illustrated by the young lover's metonymic substitution of Ingres's Turkish bather's shoulders-smooth-skinned and distantly exotic-for the doctor's wife whom he holds in an adulterous embrace. As Léon imagines the 
shoulders of one of Ingres's oriental women, his conflation enunciates and reiterates an established association of the oriental with the feminine erotic. Throughout Flaubert's writing versions of this theme abound. Masculine romantic desire is often introduced by an oriental motif: an oriental ballad accompanies Frédéric's meeting with Madame Arnoux; Salammbô's golden ankle chain piques Mâtho's desire; the Egyptian courtesan Kuchuk-Hânem uses rosewater to perfume the traveler's hands. Such associations of orientalism with romanticism are not coincidental, for the two situations of desire-the occidental fascination with the Orient and the male lover's passion for his female beloved-are structurally similar. Both depend on a structure that locates an Other-as woman, as oriental scene-as inaccessible, different, beyond. At this moment in Madame Bovary, the structural similarities make it possible for romanticism to figure itself in orientalist terms, and likewise for orientalism to figure itself in the romantic tradition.

Léon's conflation of Emma and Ingres's odalisque also reveals that some romantic and orientalist desires function fundamentally as a matter of cultural quotation, or of the repetition of cultural signs. Léon "quotes" Ingres's orientalist painting to signify and to enhance his romantic desire; but, ironically enough, the orientalist painting is itself a "quotation" of other orientalisms. We know that Ingres never traveled to North Africa or the Near East. He derived the colors and textures for his bathers and Islamic interiors from the eighteenthcentury illustrations and the descriptions he found in the letters of Lady Mary Wortley Montagu ${ }^{1}$ and in Montesquieu's Lettres persanes. The Orient of Léon's reference to Ingres is a heterogeneous amalgam: Ingres's paintings of Turkish odalisques bring together iconographies of a multiplicity of Orients-derived at times from painted scenes of Tangiers, Cairo, and Jerusalem, at other times from literary fictions of Persia. $^{2}$

In this particular example from Flaubert, we understand that orien-

1The editor of Lady Mary Wortley Montagu's Turkish Embassy Letters observes that key passages from Montagu's letters enumerating the customs and decor of the Turkish female chambers are found copied into Ingres's notebooks. See particularly "Letter to Lady_, 1 April 1717," in The Complete Letters of Lady Mary Wortley Montagu, vol. 1 (1708-1720), ed. Robert Halsband (Oxford: Clarendon Press, 1965), pp. 312-15.

${ }^{2}$ See MaryAnne Stevens, ed., The Orientalists: Delacroix to Matisse: The Allure of North Africa and the Near East (London: Weidenfeld and Nicolson, 1984), p. 17. 
talism - the tradition of occidental literary and scholarly interest in countries and peoples of the East ${ }^{3}$ - is hardly a discrete or monochromatic phenomenon. To the contrary, the representation of Léon's quotation from the Ingres painting illustrates how literary figures and narratives express a nexus of various modes of representation; in this case, romantic poetry's representation of women, orientalist literature's representation of the Orient, orientalist paintings of women, and romantic paintings of women are all enunciated in the moment when Léon substitutes the shoulders of the odalisque. As the intertextuality of this scene demonstrates, none of these individual traditions of representation can be discussed as if it were simple or uniform; nor can the social contradictions of which they are crucial representations be equated or analogized. In Flaubert's France, for example, the discursive representations of gender have social determinants-including the organization of the family, the construction of sexuality, medical practices-which are distinctly different from the conditions that produce discourses about cultural and racial differences; yet these diverse means of inscription traverse one another in Madame Bovary. The means by which the French culturally dominated and occupied Algeria after 1830, significant determinants of the discursive produc-

3Since 1838 the French term orientalisme has implied the diverse interests during the romantic period in all varieties of oriental matters, although it also included the more established meaning of oriental studies, the scholarly studies of the languages, cultures, and customs of Asiatic peoples from the Mediterranean to Japan. The term orientaliste appears in 1799 in the Magasine encyclopédique 25, 122: "Le savant orientaliste le père Paulinus," even though the Académie did not recognize it until 1835. It appears also in the Journal asiatique in 1824 in an obituary for Louis Langlès (1763-1824): "Le nom nouveau d'orientaliste sous lequel quelques personnes aiment à confondre ceux qui étudient les langues de l'Asie et ceux qui cherchent à approfondie l'histoire de cette partie du monde, ce nom aurait pu être inventé pour $\mathrm{M}$. Langlès, tant il exprimait bien ses goûts et les habitudes de son esprit." See Daniel Reig, Homo orientaliste: la langue arabe en France depuis le XIX e siècle (Paris: Éditions Maisonneuve et Larose, 1988).

Thus, orientalism was already an established term of reference for European literary and scholarly interest in the Orient when Edward Said elaborated his critique of orientalism in his 1979 work, Orientalism. Said defines the phenomenon as the body of occidental representations of the oriental world which both constitute the Orient as Other to the Occident and appropriate the domain of the Orient by speaking for it. Orientalism is a discourse, Said argues, which is on the one hand homogenizing - the Orient is leveled into one indistinguishable entity - and on the other hand anatomizing and enumerative-the Orient as an encyclopedia of details divided and particularized into manageable parts. The discourse manages and produces information about an invented Other, which locates and justifies the power of the knowledgeable European self. 
tion of cultural and racial difference, are in turn different from the circumstances of emerging industrial labor in France which gave rise to discourses about the working class. But as we will see, these distinctly different concerns overlap in the construction of the warring factions in Flaubert's Salammbô. Hence, the means of representation of various discourses are fundamentally heterogeneous and unequal; furthermore, these discursive apparatuses differ over time, and do not necessarily correspond across national and cultural boundaries. Yet, despite their essential nonequivalences, discursive means of representation overlap and are mutually implicated in one another at different moments.

My study treats orientalism as one means whereby French and British cultures exercised colonial domination through constituting sites and objects as "oriental." The discussions that follow are inscribed within an unqualified criticism of the persistent hegemonies that permit western domination of non-Europeans and the Third World. Yet, as much as I wish to underscore the insistence of these power relations, my intervention resists totalizing orientalism as a monolithic, developmental discourse that uniformly constructs the Orient as the Other of the Occident. ${ }^{4}$ Therefore I do not construct a

\footnotetext{
4This is one implication of Orientalism. Said states: "Orientalism is a style of thought based upon an ontological and epistemological distinction made between 'the Orient' and (most of the time) 'the Occident.' . . . In short, Orientalism is a Western style for dominating, restructuring, and having authority over the Orient." Edward W. Said, Orientalism (New York: Random House, 1979), pp. 2-3. It is in this sense that Homi K. Bhabha observes in "The Other Question: The Stereotype and Colonialist Discourse," Screen 24, no. 6 (November-December, 1983): "There is always, in Said, the suggestion that colonial power and discourse is possessed entirely by the coloniser, which is a historical and theoretical simplification" (p. 25). Said's tendency to generalize orientalism as a constant and monolithic discourse is also noted by others: see for example, James Clifford, "On Orientalism," in The Predicament of Culture (Cambridge, Mass.: Harvard University Press, 1988); and B. J. Moore-Gilbert, Kipling and "Orientalism" (London: Croom Helm, 1986). Moore-Gilbert, for example, argues for the need to reappraise Said's presentation of orientalism as monolithic by calling attention to the incongruity between the West's relation to Arabs and Islam and Britain's relation to India.

Since Orientalism, Said's attention to the question of a Palestinian homeland, as well as to other issues of postcolonial emergence, makes it clear that he is not a proponent of the kind of monolithic rendering that does not account for resistance on the part of the colonized. See his "Identity, Negation, and Violence," New Left Review (December 1988): 46-6o; The Question of Palestine (New York: Times Books, 1979); After the Last Sky: Palestinian Lives (New York: Pantheon Books, 1986); and, co-edited by Said and Christopher Hitchens, Blaming the Victims: Spurious Scholarship and the Palestinian Question (Lon-
} 
master narrative or a singular history of orientalism, whether of influence or of comparison. Rather, I argue for a conception of orientalism as heterogeneous and contradictory; to this end I observe, on the one hand, that orientalism consist of an uneven matrix of orientalist situations across different cultural and historical sites, and on the other, that each of these orientalisms is internally complex and unstable. My textual readings give particular attention to those junctures at which narratives of gendered, racial, national, and class differences complicate and interrupt the narrative of orientalism, as well as to the points at which orientalism is refunctioned and rearticulated against itself. I suggest that the elucidation of these heterogeneous sites may prove useful, in terms of both method and political strategy, because they mark the places where orientalism is vulnerable to challenge. In focusing my interpretations on these sites, I hope to demonstrate how the logic of a discourse that seeks to stabilize domination is necessarily one that makes possible allegories of counterhegemonies and resistances to that domination; at the same time, these allegories suggest that it may not be possible to essentialize one privileged mode or site of struggle against domination, for each site is already multiply constructed. In this sense this book is a consideration of the unevenness of knowledge formations - the nonequivalence of various orientalisms in French and British culture, and the incommensurability, within specific orientalisms, of different narratives that concurrently challenge or corroborate the power of orientalism-in order to suggest, ultimately, that a critical acknowledgment of noncorrespondence, incommensurability, and multiplicity is necessary in effective contestations of colonial domination.

\section{The Limits of Orientalism}

It is necessary to revise and render more complex the thesis that an ontology of Occident and Orient appears in a consistent manner throughout all cultural and historical moments, for the operation that lends uniform coherence and closure to any discourse risks misrepre-

don: Verso, 1988). At the same time, Said's work does continue to stress the dominance of an imperialism of a single character, and to deemphasize the heterogeneity of different imperialisms and specific resistances. 
senting far more heterogeneous conditions and operations. When Michel Foucault posits the concept of discursive formations-the regularities in groups of statements, institutions, operations, and practices-he is careful to distinguish it as an irregular series of regularities that produces objects of knowledge. In other words, a phenomenon such as the notion of the Orient in early-eighteenth-century France may be said provisionally to be constituted by some sort of regularity-that is, the conjunction of statements and institutions (maps, literary narratives, treatises, Jesuit missionary reports, diplomatic policies, and so forth) pertaining to the Orient. But the manner in which these materials conjoin to produce the category "the Orient" is not equal to the conjunction constituting "the Orient" at another historical moment, or in another national culture. With the idea of an irregular series, Foucault emphasizes that neither the conditions of discursive formation nor the objects of knowledge are identical, static, or continuous through time. In this way he seeks to avoid some of the overdetermining idealities of traditional historical study, with its desire for origins, unified developments, and causes and effects. ${ }^{5}$

In a similar manner, my book works against the historical desire to view the occidental conception of the oriental Other as an unchanging topos, the origin of which is European man's curiosity about the nonEuropean world. If we misapprehend that an object is identically constructed through time, we do not adequately appreciate that the

5Foucault devises the concept of discursive formation as part of a "historical" project that seeks to avoid some primary idealities-of origin, continuity, and developmentthat are the instruments of interpretation in traditional historical method. Conceiving of history as an irregular series of discursive formations is an alternative method that takes into account nonlinear events, discontinuity, breaks, and the transformations of both the apparatuses for producing knowledge and that which is conceived of as knowledge itself. After rejecting four hypotheses concerning the unifying principles of a discursive formation-reference to the same object, a common style in the production of statements, constancy of concepts, and reference to a common theme-Foucault characterizes the active principle of discourse as "dispersion": "Whenever one can describe, between a number of statements, such a system of dispersion, whenever, between objects, types of statement, concepts, or thematic choices, one can define a regularity (an order, correlations, positions and functionings, transformations), we will say, for the sake of convenience, that we are dealing with a discursive formation.... The conditions to which the elements of this division (objects, mode of statements, concepts, thematic choices) are subjected we shall call the rules of formation. The rules of formation are conditions of existence (but also of coexistence, maintenance, modification, and disappearance) in a given discursive division." Michel Foucault, Archaeology of Knowledge, trans. A. M. Sheridan Smith (New York: Pantheon, 1972), p. 38. 
process through which an object of difference-in this case the Orient-is constituted, is made possible, precisely by the nonidentity through time of such notions as Occident and Orient. That is, fundamental impermanence and internal discontinuity undermine the stability of both the relationship between the terms and the terms themselves. When we maintain a static dualism of identity and difference, and uphold the logic of the dualism as the means of explaining how a discourse expresses domination and subordination, we fail to account for the differences inherent in each term. In the case of orientalism, the misapprehension of uniformity prohibits a consideration of the plural and inconstant referents of both terms, Occident and Orient. The binary opposition of Occident and Orient is thus a misleading perception which serves to suppress the specific heterogeneities, inconstancies, and slippages of each individual notion. This heterogeneity is borne out most simply in the different meanings of "the Orient" over time. In many eighteenth-century texts the Orientsignifies Turkey, the Levant, and the Arabian peninsula occupied by the Ottoman Empire, now known as the Middle East; in nineteenth-century literature the notion of the Orient additionally refers to North Africa, and in the twentieth century more often to Central and Southeast Asia. Notions such as "French culture," "the British Empire," and "European nations" are likewise replete with ambiguity, conflicts, and nonequivalences. And, as we shall see, nineteenth-century British literature about India is marked by an entirely different set of conventions, narratives, figures, and genres from those in the French literature about Egypt and North Africa for the comparable period. The British and French cultural contexts for producing such literatures at that particular moment are distinct: not only are there many noncorrespondences between the individual national cultures and literatures, but also, in the nineteenth century, the governing methods derived from Britain's century-old colonial involvement in Indian culture, economy, and administration are in contrast to those typifying the French occupation of North Africa, a contrast that exemplifies nonequivalent degrees of rule and relationship.

In addition, the assumption of a unifying principle-even one that must be assumed to be partly true, that the representation of the Orient expresses the colonial relationships between Europe and the non-European world-leaves uninvestigated the necessary possibility 
that social events and circumstances other than the relationships between Europe and the non-European world are implicated in the literature about the Orient, and that the relative importance of these other conditions differs over time and by culture. To allegorize the meaning of the representation of the Orient as if it were exclusively and always an expression of European colonialism is to analyze the relation between text and context in terms of a homology, a determination of meaning such that every signifier must have one signified and every narrative one interpretation. Such a totalizing logic represses the heterologic possibilities that texts are not simple reproductions of context-indeed, that context is plural, unfixed, unrepresentableand that orientalism may well be an apparatus through which a variety of concerns with difference is figured. The Orient as Other is a literary trope that may reflect a range of national issues: at one time the race for colonies, at others class conflicts and workers' revolts, changes in sexual roles during a time of rapid urbanization and industrialization, or postcolonial crises of national identity. Orientalism facilitates the inscription of many different kinds of differences as oriental otherness, and the use of oriental figures at one moment may be distinct from their use in another historical period, in another set of texts, or even at another moment in the same body of work.

There is, of course, a very important political statement contained in the thesis that orientalism is an expression of European imperialism. Yet, when one proposes polemically that the discourse of orientalism is both discrete and monolithic, this polemic falsely isolates the notion of discourse, simplifies the power of this isolated discourse as belonging exclusively to Europe, and ignores the condition that discursive formations are never singular. Discourses operate in conflict; they overlap and collude; they do not produce fixed or unified objects. Orientalism is bound up with-indeed it reanimates some of the structuring themes of-other formations that emerge at different historical moments: the medical and anthropological classifications of race, psychoanalytic versions of sexuality, or capitalist and Marxist constructions of class. Moreover, the means of representation of any discursive production are uneven, unequal, and more and less enunciated at different moments. For example, in various texts by a single writer such as Gustave Flaubert, the representation of the Egyptian courtesan Kuchuk-Hânem in Voyage en Orient (1850) and Correspond- 
ance (1853) figures her oriental otherness in both racial and sexual terms; whereas in Salammbô (1862) the drama of the barbarian oriental tribes builds on a concurrent set of constructions of the French working-class revolts of 1848 ; and in L'éducation sentimentale (1869) the oriental motif is invoked as a figure of sentimental and romantic desire, offering a literary critique of this theme. In this sense this orientalist situation represented in Flaubert's texts is hardly uniform or monolithic; rather, it constitutes a site in which a multiplicity of heterogeneous discourses engage and overlap, not limited to dominant orientalist formations but also including emergent challenges to those formations. The orientalizing figures articulated in Salammbô and Voyage are imitated and parodied in L'éducation sentimentale; the textual instabilities of Flaubert's divided corpus mark those moments in which orientalist domination is simulated and then troubled, counterfeited and then ironically mocked.

An examination of the broader discursive relation between dominant formations and the emergent critiques of those formations provides a further opportunity to appreciate the multivocal character of discursive terrains. In Chapter 4 I pursue this theme of discursive heterogeneity by considering the interventions of Indian scholars into the exclusive tradition of Anglo-American literary criticism of E. M. Forster's Passage to India. To the degree that dissenting positions and practices are implicated in the very formations they address and oppose, the articulations of resistance and opposition by emergent or subaltern positions are not in themselves necessarily powerful or transforming. But, as the Forster debates illustrate, every position and practice shifts the conditions and alters the criteria, arguments, and rhetorical terms of enunciation and formation in the discourse. In this sense power is not static, nor does it inhere in an agency or a position or practice in itself; rather, it is found in the spatial and relational nonequivalences of the discursive terrain, in the active shifting and redistribution of the sites of inscription.

As I do not consider orientalism to be a continuous and discrete formation that constitutes a stable, essentialized object, the Orient, in this study I consider four orientalist situations that exemplify a heterogeneous variety of discursive formations of cultural difference. The social and historical context is different in each case, and the variety of literary materials is also heterogeneous, including travel narratives, 
letters and correspondence, novels, literary criticism, and literary theories. Rather than suggesting that there is an evolution or development of a uniform notion of the Orient as Other from the eighteenth through the twentieth centuries, I argue precisely the opposite: although it may be possible to identify a variety of different models in which otherness is a structuring trope, these differences demonstrate that to discuss a discourse of otherness is to attempt to isolate and arrest an operation that is actually diverse, uneven, and complicated. Even as I bracket the "discourse of otherness" as a heuristic notion, my ultimate purpose is to present a series of observations that provides the basis for resisting and challenging the notion of a closed discourse that manages and colonizes otherness. I should say that one of the paradoxes built into my discussion is that even as I argue against the closure or singularity implied by the term discourse, I must name it in order to write about it. Thus I encounter the problem of what to call this nexus of apparatuses that is not closed but open, not fixed but mobile, not dominant although it includes dominant formations, and so forth. Rather than placing discourse in quotation marks each time I want to call its monolithic quality into question, I hope it is understood that I refer to discourse with the faith that the reader follows my intention to displace a fixed, discrete, exclusive notion with one that implies a multivalent, overlapping, dynamic terrain.

\section{Discourse, Heterotopia, Hegemony, Subalternity}

In the readings that follow, I am interested in tracing the discursive intersections in particular French and British orientalist situations; these moments of intersection destabilize the power of orientalism, and the conflicts and convergences among different productions of otherness mark places from which resistances to orientalism may be articulated. It is useful here to define and interpret some of the terms, and their implied theoretical projects, that form the basis for these readings. Although the starting point for my critique of orientalism is Foucault's concept of discourse, his use of the term is both ubiquitous and inconsistent. In order to redefine discourse and to be specific about my use of the term-as an open, mobile terrain of overlapping formations-I situate Foucault's concepts of discourse and heterotopia in 
relation to Antonio Gramsci's theories of cultural hegemony and subalternity. In bringing together these diverse ideas, I sketch a picture of cultural production in which discourse designates the complex and uneven terrain composed of heterogeneous textual, social, and cultural practices; this is the terrain on which the organization of social life, or cultural hegemony, is achieved, maintained, challenged, and ultimately transformed.

Although I concede an essential incongruity between Marxian and Foucauldian paradigms and methods, I believe that there is an important dialogue to be posited between Foucault's notion of discourse and the Marxist concept of hegemony, and in particular the notion of hegemony elaborated by Gramsci as the entire social process through which a particular group exercises dominance. ${ }^{6}$ On the one hand, bringing a Marxist discussion of hegemony to bear on Foucault's notion of discourse can elaborate the persistent, though not exclusive, role of economic forces in the production of cultural practices, supplementing what remains obscure in Foucault's work regarding the role and character of the practices that affect discursive transformation. Furthermore, Gramsci's concept of the "subaltern" classes-the emergent, not yet unified groups who may ally to create a "new historical bloc" - begins to open up, within a Foucauldian idea of discourse, specific and concrete arenas of dissent, resistance, accommodation, and change. On the other hand, the Foucauldian critique of totalizing narratives, unities, and origins can modify the tendency of some Marxist theories to isolate the notions of economic base and ideological

\footnotetext{
6It is apparent from the outset that the purposes and methods of Marx and Foucault are fundamentally incompatible. The Marxian paradigm emphasizes the productive structure of the economic in relation to a cultural superstructure, whereas in Foucault the importance of economic structure is diminished in relation to the greatly emphasized discursive modes of production. To the former, power refers to the economic power of one class over others, and history is the history of class struggle, whereas in the theories of the latter, power is at once hypostasized and pervasive, inscribing all areas of human life: social, intellectual, sexual, and so on.

Foucault's project is generally hostile to, and critical of, the most traditional Marxist narratives (a totalized history of class struggle, economic determinism, zero-sum notions of class hegemony) which Foucault's theories would deem too fixed and absolute, themselves parts of a discursive production of false origins, unities, and objects. The most traditional Marxism, by contrast, would view Foucault's theory, which emphasizes the productive power of discourse, as misguided and exemplifying the false consciousness that supports bourgeois class hegemony to the degree that it prevents oppressed classes from recognizing the revolutionary means necessary to throw off their oppression.
} 
superstructure and to understand the former as determining the latter. Foucault's premise-that power is not localized in or limited to a ruling body but saturates the entire discursive field—brings to Marxist discussions of hegemony the possibility of many diverse forms of struggle, including those not easily recognizable as political or economic. This de-essentialized understanding of power is consonant, too, with my discussion of orientalism as a discursive formation not exclusively deployed by European or colonial rule, but articulated alternately and simultaneously by a variety of dominant and emergent positions on the discursive terrain.

In discussing discourse, I am invoking Foucault's notion to refer to networks of texts, documents, practices, disciplines, and institutions, which together function as matrixes in the production of certain objects and forms of knowledge. For Foucault, discourses can both discipline and manage forms of human subjectivity by constituting classifications such as madness, sexual deviance, and racial inferiority; these discourses regulate objects of knowledge through a variety of means, including criteria that exclude, limit, or eliminate. The discursive management of race is among the topics examined in Donna Haraway's work, for example; she writes about instances in the western scientific discourse of primatology in which Africa was conflated with primates and thus African races were discursively excluded from definitions of human species; this exclusion was instrumental in establishing and maintaining the coherence of the European races as well as the legitimacy of racism and colonialism. ${ }^{7}$ Foucauldian method is likewise concerned with the productive function of discursive controls and exclusions; paradoxically, discursive means of appropriation and policing are accompanied by articulations of responses to these prohibitions, which are themselves enunciations of categories that are being policed. In this sense we might understand certain forms of African nationalism as responses generated, in part, from positions policed and excluded by racism or colonialism. ${ }^{8}$ Because Foucault's

TDonna Haraway's far-reaching book, Primate Visions: Gender, Race, and Nature in the World of Modern Science (London: Routledge, 1989) can hardly be paraphrased in a brief sentence; I am drawing out only one strand of a complex weave of arguments.

8In Les damnés de la terre (Paris: F. Maspero, 1961), for example, Frantz Fanon suggests that the bourgeois nationalism practiced by neocolonial governments may be linked to, and implicated in, the structures of the former colonialism. Although Fanon stresses that nationalism and African unity are crucial concepts in the struggles of independence groups against colonialism and cultural obliteration, he also argues that bourgeois nationalism is easily perverted into forms of racism and separatism in which the colonial 
books on madness, the prison system, and sexuality imply that resistance to exclusion and prohibition is itself implicated in discursive regulation, his work has often been interpreted by some readers as asserting the omnipotence of discursive apparatuses, the unchanging regulation of the social field, and, equally, the impossibility of resistance or dissent, which is not inevitably incorporated in the dominant terms of the discourse. To the contrary, it seems to me that Foucault refers generally to transformations of the social field, as well as to the disruption and change of discursive apparatuses. Foucault does not describe these changes as being enacted by individual agents necessarily in anticipated forms of resistance; rather, he sees them as originating in other practices and from unexpected sites and functions on the social terrain. ${ }^{9}$ Foucault writes:

The positivities that I have tried to establish must not be understood as a set of determinations imposed from the outside on the thought of indi-

power is replaced by an ethnic group while the order of social relations remains the same. Ironically, these tribal separatisms, or "micro-nationalisms," are congruent with the logic of colonialism, and are themselves legacies of the colonial structure.

Fanon's argument- that decolonization may either provide for a new set of relationships or reproduce the old order-illustrates precisely the problem of transforming structures of discipline, regulation, and power, a matter that is left inexplicit by Foucault, and one that critics after him have often debated. Fanon's discussion of decolonization suggests that interventions, resistances, and even changes of government or political party do not in themselves guarantee that a changed order or changed social relations will result; of utmost importance are the sites from which interventions originate, as well as the nature of these interventions. In Fanon's account, the old logic and social relations persist, particularly through the ties of the national bourgeoisie to the colonial order, and the racism inherited from the colonial order cannot be expelled in decolonization except through a deep, fundamental transformation of the social and material relations of colonialism. This work of transformation does not come from the national bourgeoisie, he suggests, but is generated "sous la poussée et sous la direction des peuples, c'est-à-dire au mépris des intérêts de la bourgeoisie" (p. 124) (through the upward thrust of the people, and under the leadership of the people, that is to say, in defiance of the interests of the bourgeoisie).

Foucault's theories never achieve the levels of either concreteness or practical engagement that Fanon's work epitomizes; and indeed, although the two men are not historically dissimilar (Foucault, a Frenchman writing after 1968, and Fanon, a Martiniquan who worked as a doctor in Algeria during the Algerian war) they write from very different social positions on the question of race and colonialism. Yet I juxtapose the two in order to suggest that the kinds of interventions described by Fanon are not precluded by Foucault's concept of discourse, and indeed may be the sort of intervention to lend concreteness to Foucauldian discussions.

"By "anticipated" and "unexpected" I do not mean to imply that there is somehow a central agency that controls forms of resistance. Rather, I mean to invoke a sense of temporality; the sites, functions, and practices of resistance that succeed in transforming the specific hegemonies in discourse may be identifiable only in hindsight. These forms 
viduals, or inhabiting it from the inside, in advance as it were; they constitute rather the set of conditions in accordance with which a practice is exercised, in accordance with which that practice gives rise to partially or totally new statements, and in accordance with which it can be modified. These positivities are not so much limitations imposed on the initiative of subjects as the field in which that initiative is articulated (without, however, constituting its centre), rules that it puts into operation (without it having invented or formulated them), relations that provide it with a support (without it being either their final result or their point of convergence). It is an attempt to reveal discursive practices in their complexity and density; to show that to speak is to do something ... to show that a change in the order of discourse does not presuppose "new ideas," a little invention and creativity, a different mentality, but transformations in a practice, perhaps also in neighboring practices, and in their common articulation. I have not denied-far from it - the possibility of changing discourse: I have deprived the sovereignty of the subject of the exclusive and instantaneous right to it. ${ }^{10}$

Foucault does not describe the regulating activity of discourse as either a set of fixed laws imposed from the outside or a series of determined utterances recited by individuals. Rather, discourse is a changing set of conditions that regulates the range of possible articulations at any time; yet with each articulation, the set of conditions shifts and adapts. The transformation of the set of conditions includes not only changes in the means of regulation but also modifications of the means and relations of representation as well, changes in the frequency and modes of articulation, fluctuations in locus and register, and ultimately "partially or totally new statements . . . in accordance with which it can be modified." In Chapter 4, for example, I observe that when Indian scholars enter the previously exclusive Anglo-American field of Forster studies, they alter the conditions of the discourse. Their interventions shift the criteria for inclusion and exclusion as well as the permissibility of certain subjects and objects of discourse. A condition

of resistance are not "anticipated" in the sense that at the moment of their articulation they may not be understood as transforming, whereas other forms deemed as such may ultimately be appropriated or neutralized.

${ }^{10}$ Foucault, Archaeology of Knowledge, p. 209; emphasis added. This is one of the rare texts in which Foucault outlines his method. In citing it I want to be careful not to represent it as the "real Foucault," or the key to understanding Foucault. For amidst Foucault's "histories" in which method is not delineated but is demonstrated-for example, Madness and Civilization, Discipline and Punish, The Birth of the Clinic, and The History of Sexuality - Archaeology is an anomaly. 
of multiple and interpenetrating positions and practices-what we might call heterotopicality - is one way of describing the dynamic through which discursive conditions are transformed.

By heterotopicality I mean several things: first, I am evoking the sense in which discursive terrains are spatial and are composed of a variety of differently inscribed and imagined locations. The first and more general sense of heterotopicality-as a heterogeneous spatial designation-I derive from Foucault's notion of heterotopia. ${ }^{11}$ Foucault argues that in institutional and social practices, certain spaces are coded as "public" and others as "private," some domains "legal" and others "illegal," some areas are for "work" and others for "play," and so on. He further distinguishes between cultural designations of utopias, which are the imaginary inversions of the real spaces of society, and heterotopias, which he describes as spaces of otherness: spaces of crisis, illiteracy, deviance, enslavement, or colonialism. Second, I want to render more complex Foucault's sense of oppositional spatial heterogeneity by taking it out of its ultimately binary frame of oppositions to recast spatial difference in terms of multiple sites. That is, on discursive terrains, such as the one in which orientalism is one formation, articulations and rearticulations emerge from a variety of positions and sites, as well as from other sets of representational relations, including those that figure class, race, nation, gender, and sexuality. Some of these articulations may intervene in and contest orientalist formations, while others may reiterate them. Each articulation shifts and alters the terms, conditions, and emphasized sites of the terrain. In this sense I employ the term heterotopicality to refer to this sense of multiplicity and interpenetration-the continual yet uneven overlappings, intersections, and collusions of discursive articulations.

This expanded notion of multiple spatial differences within discursive fields necessarily leads us to consider the processes through which certain formations maintain dominance over time, and in turn the processes through which resistance to these formations is suppressed or incorporated. In this effort the Marxist notion of hegemony provides a useful model. Although hegemony has been traditionally defined as political rule or economic domination in the relations be-

\footnotetext{
${ }^{11}$ Foucault's notion of heterotopia is elaborated in a posthumously published text "Des espaces autres," translated by Jay Miskowiec in Diacritics 16, no. 1 (Spring 1986):22-27, as "Of Other Spaces."
} 
tween social classes, in Gramsci's thought hegemony is elaborated as a much broader notion, one that also includes the complex interconnected relations between social, cultural, and ideological practices through which a ruling group exercises domination. Hegemony is Gramsci's way of describing the entire process of negotiation, dissent, and compromise whereby a particular group or ideological formation gains the consent of the larger body to lead. In this sense hegemony does not refer exclusively to the process by which dominant groups exercise and maintain influence, but it denotes equally the process through which other groups organize, contest, or accommodate any specific domination. It is thus a question of a hegemonic process rather than a static or monolithic condition. ${ }^{12}$ In this notion of hegemony, the older idea of domination by a ruling class is rethought. The ruling group is no longer an externalized body, and is no longer exclusively class-defined; rather, a specific domination is reconceptualized as a system of internalized practices and alliances within culture. ${ }^{13}$ One

12 The notion of "the dominant" - defined by Raymond Williams ("Dominant, Residual, and Emergent," in Marxism and Literature [New York: Oxford University Press, 1977]) as "a cultural process . . . seized as a cultural system, with determinate dominant features: feudal culture or bourgeois culture or a transition from one to the other" - is often conflated in cultural theory with Gramsci's concept of hegemony. Indeed, Williams writes, "We have certainly still to speak of the 'dominant' and the 'effective,' and in these senses of the hegemonic" (p. 121), as if the "dominant" and the "hegemonic" were synonymous.

It is important to note, however, that in Gramsci's thought, hegemony refers equally to a specific hegemony (for example, bourgeois class hegemony) and to the process through which "emergent" groups challenging that specific hegemony assemble and contest the specific ruling hegemony.

${ }^{13}$ Gramsci's concept of hegemony integrates two poles in Marxist theories of social change. On the one hand, it goes beyond the earlier concepts of superstructure and ideology-the system of ruling ideas characteristic of a particular class group-to describe an integrated system in which the production, practice, and proliferation of those ideas are only one part. On the other hand, Gramsci transforms the Marxist concept of class rule.

Originally, superstructure or ideology referred to a set of "ruling ideas" that mirrored the economic dominance of the ruling class. In "The German Ideology" (in Marx-Engels Reader, ed. Robert C. Tucker [New York: Norton, 1971], p. 136), Marx writes of ideology as "ruling ideas . . . the ideal expression of dominant material relationships."

Neo-marxist theorists, however, have since greatly expanded and complicated the understanding of ideology as ruling ideas that reflect economic relations: Georg Lukács, by providing a dialectical theory of the historical novel and its historical and social context, considerably elaborated the dialectic between form and context, consciousness and history; the Frankfurt School, especially Walter Benjamin and Theodor Adorno, in theorizing culture as an area of production. Finally, the concept of structural causality 
might say that hegemony is also the process by which a particular group becomes "the one" in relation to which others are defined and know themselves to be Other.

In Gramsci's discussion of the levels of the "relations of force," it is clear that the hegemony of a specific group over a series of subordinate groups is never stable or static. ${ }^{14}$ The relation of political forces, for example, is measured in the fluctuating degrees of homogeneity, selfawareness, and organization attained by the various social classes. In The Prison Notebooks Gramsci describes this relation of political forces as varying and mutable: "The dominant group is coordinated concretely with the general interests of the subordinate groups, and the life of the State is conceived of as a continuous process of formation and superseding of unstable equilibria . . . between the interests of the fundamental group and those of subordinate groups-equilibria in which the interests of the dominant group prevail, but only up to a certain point." 15 By implication, the reality of any specific domination is that, although it may be powerful for the moment, its power to dominate is never absolute or conclusive. A specific domination is not static; it is a process through which a particular group overtly or covertly gains the consent of other groups to determine the political and ideological state of the society, a much more complicated process than either the imposition or the reproduction of an unmodified rule. In this sense, when a hegemony representing the interests of a dominant group exists, it is always within the context of resistance from, and compromises with, "subaltern"16 groups. Orientalism, then, as a formation that figures the domination of one group by another, never achieves static domina-

with regard to ideology is posited by the French structuralist Marxist Louis Althusser, later critiqued and refined in the work of Fredric Jameson in the concept of "structure as absent cause." See, most particularly, Jameson, The Political Unconscious: Narrative as a Socially Symbolic Act (Ithaca: Cornell University Press, 1981), chapter 1, pp. 17-102.

${ }^{14}$ The "relations of force" are the complex relation of different moments or levels, including the relation of social forces to the material forces of production, the relation of political forces, and the relation of military forces. Gramsci describes these moments as implying one another reciprocally - differing in accordance with socioeconomic activity and across different countries-combining and diverging in various ways.

${ }^{15}$ Antonio Gramsci, Selections from "The Prison Notebooks," ed. and trans. Quintin Hoare and Geoffrey Nowell Smith (New York: International Publishers, 1971), p. 182.

${ }^{16}$ Gramsci describes "subaltern" groups as by definition not unified, emergent, and always in relation to the dominant groups; the subaltern groups may have passive or active affiliations to the dominant political formations; they may produce new formations that assert the autonomy of the subaltern groups but are within the old framework. 
tion; orientalism, as an expression of colonialism, exists always amid resistance from subaltern or emergent spaces on the discursive terrain.

Gramsci defines the subaltern classes as prehegemonic groups whose histories are fragmented, episodic, and identifiable only from a point of historical hindsight. These classes are, in Gramsci's definition, "not unified" (p. 52) and may go through different phases during which they are subject to the activity of ruling groups; they may articulate their demands through existing parties, and then may themselves produce new parties. Gramsci, however, describes a phase at which the "formations [of the subaltern classes] assert integral autonomy" (p. 52). Although what is meant by "integral autonomy" is not immediately apparent, and indeed is the subject of debate, Gramsci's definition includes some noteworthy qualifications. The condition that the significant practices of the subaltern groups may not be understood as hegemonic until they are viewed with historical hindsight is interesting, for it suggests that the some of the most powerful practices may not be the overtly oppositional ones, may not be understood by their contemporaries, and may be less overt and recognizable than others. That the subaltern classes are by definition not unified is also a key point; that is, the subaltern groups do not constitute a fixed, unified force of a single character. Rather, the assertion of integral autonomy by subaltern classes that are not unified suggests a coordination of discrete yet allied movements, each in its own not necessarily equivalent manner transforming, disrupting, and destructuring the apparatuses of a specific hegemony. In this sense the hegemonic process described by Gramsci consists of a continuously transforming and variable relationship between dissenting, intervening, and accommodating positions and practices and the current dominant for-

\footnotetext{
"The history of subaltern social groups is necessarily fragmented and episodic. There undoubtedly does exist a tendency to (at least provisional stages of) unification in the historical activity of these groups, but this tendency is continually interrupted by the activity of the ruling groups; it therefore can only be demonstrated when an historical cycle is completed and this cycle culminates in a success. Subaltern groups are always subject to the activity of ruling groups, even when they rebel and rise up: only 'permanent' victory breaks their subordination, and that not immediately. In reality, even when they appear triumphant, the subaltern groups are merely anxious to defend themselves (a truth which can be demonstrated by the history of the French Revolution at least up to 1830). Every trace of independent initiative on the part of subaltern groups should therefore be of incalculable value for the integral historian." Gramsci, "History of the Subaltern Classes: Methodological Criteria," in Selections from "The Prison Notebooks," pp. 54-55.
} 
mation. The independent forms and locations of cultural challengeideological as well as economic and political-make up what Gramsci calls a "new historical bloc," a new set of relations that together embody the possibility of a different hegemony and a different balance of power. Thus, in Gramsci's thought the concept of hegemony not only includes the accepted meaning of hegemony maintenance but carries the significance of hegemony creation as well. ${ }^{17}$

Hegemony remains a suggestive construct in Gramsci, however, rather than an explicitly interpreted set of relations. Thus, contemporary readers face the task of distinguishing which particular forms of challenge to an existing hegemony are significantly transforming, and which forms may be neutralized or appropriated by that hegemony. Some cultural critics contend that counterhegemonic forms and practices are tied by definition to the dominant culture, and that the dominant culture simultaneously produces and limits its own forms of counterculture. ${ }^{18}$ Others suggest that because identifiable variation occurs in the social order over time, as well as variations in the forms of the counterculture in different historical periods, we must conclude that some aspect of the oppositional forms is not reducible to the terms of the original hegemony. ${ }^{19}$ Still others have expanded Gramsci's no-

\footnotetext{
17Walter Adamson, in Hegemony and Revolution: A Study of Antonio Gramsci's Political and Cultural Theory (Berkeley: University of California Press, 1980), reads The Prison Notebooks as the postulation of Gramsci's activist and educationalist politics; in chapter 6 he discusses Gramsci's two concepts of hegemony: hegemony as the consensual basis of an existing political system in civil society, as opposed to violent oppression or domination; and hegemony as a historical phase of bourgeois development in which class is understood not only economically but also in terms of a common intellectual and moral awareness, an overcoming of the "economic-corporative" phase. Adamson associates the former, hegemony in its opposition to domination, with "hegemony-maintenance" and the latter, hegemony as a stage in the political moment, as "hegemony-creation."

Anne Showstack Sassoon ("Hegemony, War of Position, and Political Intervention," in Approaches to Gramsci, ed. Anne Showstack Sassoon [London: Writers and Readers, 1982]) provides discussions of Gramsci's key concepts; she historicizes the concept of hegemony and discusses the implications of some of the ways in which it has been interpreted. Sassoon emphasizes the degree to which hegemony is opposed to domination to evoke the way in which one social group influences other groups, making certain compromises in order to gain the consent of others for its leadership in society as a whole.

18Some of the "new historicist" studies of Shakespeare and Elizabethan England illustrate this conflation of hegemony with the dominant, suggesting that forms of subversion are ultimately contained by dominant ideology and institutions. See Stephen Orgel, The Illusion of Power (Berkeley: University of California Press, 1975); and Stephen Greenblatt, "Invisible Bullets: Renaissance Authority and Its Subversion," Glyph 8 (1981): 40-61.

${ }^{19}$ See Williams, Marxism and Literature, p. 114.
} 
tion of hegemony to argue that the social field is not a totality consisting exclusively of the dominant and the counterdominant, but rather that "the social" is an open and uneven terrain of signifying practices, some of which are neutralized, while others can be linked together to build pressures against an existing hegemony. ${ }^{20}$

I take up this last notion of expanded, or nontotalized, hegemony by reading specific discursive incongruities and intersections as possible sites of subaltern resistance and intervention. The orientalist situations discussed in the chapters that follow embody discursive conflicts and collaborations that express the instability of the orientalist terrain. This instability is illustrated in the confluences and deviations of other discourses with orientalism and the convergences of multiple, uneven discursive productions-such as those of gender, race, and class-not only circumscribe sites of instability in the discourse, but also permit the rise of new positions, practices, and alignments which are instrumental in the transformation of the prior discursive arrangements and the generation of new conditions. Such convergences are the topic of Chapter 2, which includes an analysis of the conflicts between British orientalism, an emergent feminism, and representations of class and privilege in Lady Mary Wortley Montagu's Turkish Embassy Letters.

Discursive instability is also produced by the relationships between dominant and emergent formations, as well as by the multiplicity and

20See Ernesto Laclau and Chantal Mouffe, Hegemony and Socialist Strategy (London: Verso, 1985), esp. pp. 134-45. Laclau and Mouffe interpret hegemony as a political relation that takes place in a "field of articulatory practices." Laclau and Mouffe make two important distinctions concerning these articulatory practices: first, they are not in themselves sufficient to constitute hegemonic change, for it is also necessary that the articulations take place through a confrontation with antagonistic articulatory practices; and second, at the same time, not every antagonism determines that a hegemonic formation will emerge. An antagonism arises when a collective subject or group finds its subjectivity negated by other discourses and practices; this negation can be, but is not necessarily, the basis for an antagonism. Finally, they argue persuasively that no hegemonic logic can account for the totality of the social, and that the open and incomplete character of the social field is the precondition of every hegemonic practice. For if the field of hegemony were conceived according to a zero-sum vision of possible positions and practices, then the very concept of hegemony, as plural and mutable formations and relations, would be rendered impossible.

Elsewhere ("Hegemony and New Political Subjects: Toward a New Concept of Democracy," in Marxism and the Interpretation of Culture, ed. Cary Nelson and Lawrence Grossberg [Urbana: University of Illinois Press, 1988], pp. 89-104), Mouffe goes even further, elaborating the practical dimensions of the hegemonic principle in terms of the efficacy of contemporary social movements in the struggle for increased democratization. 
lack of closure characteristic of both dominant and emergent sites. In Chapter 3 I observe that although colonialist, capitalist, and romanticist formations intersect in the Flaubert's early work, these formations are challenged by an emergent critique in the later text L'éducation sentimentale. The example of the Indian scholars' critique of AngloAmerican Forster criticism discussed in Chapter 4 also exemplifies dialogues between dominant and emergent positions. But it is not only difference that is represented by the debates between Indians and Anglo-Americans; it becomes clear that there is diversity among the Indian scholars as well as in the prevailing Anglo-American tradition. In Chapter 5 the utopian constructions of China by Julia Kristeva, Roland Barthes, and the journal Tel quel, illustrate yet another confluence of diverse discourses-feminism, semiotics, and French Maoism-that essentialize China as the Other. These theorists deploy an orientalist trope in order to critique a wide range of logics of domination, yet their arguments tend to contribute to the very logics they wish to criticize. In this sense my discussion of theorists in Paris during the 1970s suggests that discursive heterogeneity in itself is not enough to destabilize a particular hegemony. Rather, the historical circumstances surrounding interventions (in the case of Kristeva, Barthes, and Tel quel, I suggest that these circumstances included the events of May 1968), as well as the rhetoric and logic of these interventions, are of crucial importance. This final example of orientalism cautions us, as contemporary readers, to theorize our own positions and to scrutinize the logic through which we formulate our criticisms.

\section{Rereading Difference, Resisting Otherness}

The analysis of how nondominant races, cultures, economic groups, and sexualities are marked and figured as Other, or as the subordinated counterpart of the dominant privileged categories, has been crucial to the current project of cultural criticism. At particular moments in critical theory in the United States, criticism that makes use of the category of the Other has been powerful, illuminating, and transforming. These moments are marked by the publication of works such as Juliet Mitchell's Psychoanalysis and Feminism (1974), Gayatri Spivak's introduction to her translation of Jacques Derrida's Of Grammatology 
(1976), and certainly Said's Orientalism (1979). These represent vital veins of scholarship that have appropriated the notions of difference and otherness from philosophical and psychoanalytic traditions, redefining them in terms of contemporary interpretive concerns. ${ }^{21}$ Theories of colonialist discourse, feminism, ethnic studies, and deconstruction have, each in their own way, dramatically altered the objects, methods, and community of literary and cultural criticism. Studies of colonialist discourse have suggested that a coherent and dominant European colonial identity is represented and justified in terms of the subordination of non-European cultural and racial differences. ${ }^{22} \mathrm{Femi}-$

21The categories of difference and otherness come to literary studies from other disciplines and frames of reference. Difference, invoked in a dualistic opposition to the same, or identity, has roots in philosophical discourse. These distinctions from Greek philosophy were recapitulated in modern Continental thinking, notably by Hegel, Heidegger, and Sartre. See G. W. F. Hegel, Phenomenology of Mind, trans. J. B. Baillie (London: Macmillan, 1910), particularly "Independence and Dependence of Self-Consciousness: Lordship and Bondage" (pp. 228-40). Heidegger's mit-Sein, or "being-with," is integral to the concept of being-in-the-world. See Martin Heidegger, Being and Time, trans. John Macquarrie and Edward Robinson (1962). Finally, see Sartre's discussion of the gaze of the Other and being-for-others, in Jean-Paul Sartre, L'être et le néant: Essai d'ontologie phénoménologique (Paris: Gallimard, 1943), esp. "Le pour-autrui," pp. 265-349.

Otherness, posited in relation to a notion of the self, is a concept borrowed from psychoanalysis. Melanie Klein is greatly responsible for elaborating Freud's initial observations of the role of the female mother as Other and for considering the consequences of otherness in identity formation, and in the division, creation, and projection of "good" and "bad" objects; see MelanieKlein, Developments in Psycho-Analysis (New York: Da Capo, 1952).

For Jacques Lacan, otherness is more metaphorical and less stable. He designates the "autre" with a small $a$ to refer to object choices, the alter egos, or the counterpart, of the psychoanalytic subject; but, there is also the "Autre" or "grand Autre" (the capitalized Other), which alludes to a generalized, intersubjective field of relations. This "grand Autre" is the Other of Lacan's now famous formulation, "The unconscious is the discourse of the Other," an abbreviation of the much more complicated consequences of Lacan's rereading of Freud. For Lacan, the unconscious is structured like a language, subject to the organizing principles of condensation and displacement (like Roman Jakobson's linguistic principles of metaphor and metonymy); the psychoanalytic subject is split, both situated by language and cut off from that subject position; language is the field in which the Other speaks the subject, and through which desire for the other is enunciated, necessitated by the gap between the split-off subject and its incommensurate signifier. See Jacques Lacan, "The Function of Language in Psychoanalysis," in The Language of the Self, trans. with notes and commentary by Anthony Wilden (Baltimore: Johns Hopkins University Press, 1968).

22See, for example, Abdul R. JanMohamed, Manichean Aesthetics: The Politics of Literature in Colonial Africa (Amherst: University of Massachusetts Press, 1983); Christopher Miller, Blank Darkness: Africanist Discourse in French (Chicago: University of Chicago Press, 1985); David Lloyd, Nationalism and Minor Literature: James Clarence Mangan and the Emergence of Irish Cultural Nationalism (Berkeley: University of California Press, 1987); 
nist analyses have likewise made use of the notion of otherness to argue that the centrality of masculine identity is signified through the objectification of woman as Other, and that the mark of otherness suppresses the representation and signifying activities of women as social subjects. ${ }^{23}$ Various challengers of the notion of literature have conceived of difference as that which is absent from or suppressed by literary traditions, and have suggested that the acceptance of a closed and unrevised canon of texts privileges certain national cultures, as well as certain classes and genders, as producers of "high culture." This approach urges the reconceptualization of literary traditions to include not only literature by women, non-Europeans, and ethnic minorities, but also materials that might be categorized as nonliterary-scientific and historical documents, diaries, and products of mass or popular culture. ${ }^{24}$ Finally, deconstructive literary criticism suggests that difference manifests itself as a fundamental paradox embedded in the literary figures of the text and advocates methods of reading that would shed light on these rhetorical paradoxes. ${ }^{25}$

and Patrick Brantlinger, Rule of Darkness: British Literature and Imperialism, 1830-1914 (Ithaca: Cornell University Press, 1988). Said's Orientalism can be said not only to be responsible for legitimizing an area of colonialist discourse studies, but also to have initiated a questioning of scholarly assumptions in several disciplines, not the least of which is a serious ongoing interrogation of ethnographic practices within the field of anthropology. The significant debates in anthropology are represented best by two volumes: Writing Culture, ed. James Clifford and George Marcus (Berkeley: University of California Press, 1986); and Anthropology as Cultural Critique, ed. George Marcus and Michael M. J. Fischer (Chicago: University of Chicago Press, 1986). For Said's contributions to these debates, see "Representing the Colonized: Anthropology and Its Interlocutors," Critical Inquiry 15, no. 2 (Winter 1989): 205-25.

${ }^{23} \mathrm{An}$ ever-growing body of feminist theory employs an analysis of the construction of otherness to critique rigorously the epistemological assumptions of many disciplines. See, for example, Page duBois 1982, 1988; Teresa de Lauretis 1984; Alice Jardine 1985; and Gayatri Spivak 1988a.

${ }^{24}$ The troubling of the oppositions between "literary" and "nonliterary" materials, and between "high" culture and "popular" culture has had consequences for a variety of works: feminist criticism interested in legitimizing genres, authors, and forms of women's writing that had been excluded from consideration by previous criteria (Gilbert and Gubar 1979, 1985; Kathryn Shevelow 1989); the growing discipline of ethnic studies establishing the scholarly value of Chicano (Marta Sanchez 1985), Asian American (Elaine Kim 1982), and African-American (Barbara Christian 1980) literatures; postmodernist challenges to modernist paradigms of culture (Hal Foster 1983); and varieties of "new historicism" emphasizing that historical, scientific, and medical documents may be of equal importance with literary texts (Leonard Tennenhouse 1986.)

${ }^{25}$ Jacques Derrida $(1973,1976,1979)$ notes that the French verb différer contains both a sense of the nonequivalent, as in "to differ," as well as a sense of the same, or of a series 
Although this book is clearly implicated in these critical debates about difference and otherness, I argue finally against the recuperation of any binary version of difference. For I suggest that binary constructions of difference-whether Occident and Orient, male and female, or a static concept of dominant and emergent-embody a logic that gives priority to the first term of the dyad while subordinating the second. Whether the pair is figured as a binary synthesis that considers difference as always contained within the "same," or as one that conceives of the pair as a totality in which difference structurally implies sameness - or even if difference is posited as a third term, an absolute alterity outside the structure of binaries-it is necessary to understand each of these figurations as versions of the same binary logic. Ironically, even the positing of an outside third term depends on a binary opposition between structure and nonstructure, or insidethe-binarism and outside-the-binarism; the closure and uniformity of the Hegelian dialectic is upheld. My argument for heterogeneity seeks to challenge the tradition that conceives of difference as exclusively structured by a binary opposition between two terms-represented by the orientalist logic of Occident and Orient-by proposing instead another notion of difference that takes seriously the conditions of heterogeneity, multiplicity, and nonequivalence. I suggest that the desire to classify unevenness, incongruity, and noncorrespondence in terms of binary models of difference is based on a logic inscribed by discourses of domination, and that to conform to binary difference is inevitably to corroborate the logic of domination, to underdevelop the spaces in discourse that destabilize the hegemony of dominant formations. Mine is neither a philosophical nor an exclusively literary pursuit, one that might find the ultimate otherness of discourse in language, in the interaction of the poetic with the representational. Rather, I identify heterotopic spaces from which new practices are generated at the intersections of unevenly produced categories of otherness, in the junctions, overlaps, and confluences of incommensurable apparatuses which are not primarily linguistic but practical and material.

Because logics of domination and subordination are embedded

of identities separated by gaps, as in "to defer." Deconstructionist literary criticism (Paul de Man 1979; Barbara Johnson 1980) explores this paradoxical quality of opposition and reversal in rhetorical and literary figures. 
within binary conceptions of difference, one risks certain dangers in continuing to essentialize notions of either the Other or its foe the dominant discourse. Not only does the essentializing of otherness inadvertently valorize, by further enunciating, the powerful hegemonies it seeks to criticize, but also theories that create monoliths of managing discourses greatly underestimate other points and positions of struggle and resistance operating in a specific hegemony at any moment. The view that a dominant discourse produces and manages otherness, univocally appropriating and containing all dissenting positions within it, underestimates the tensions and contradictions within any discursive terrain, the continual play of resistance, dissent, and accommodation. Most important, this type of dominant discourse theory minimizes the significance of counterrepresentations and countercultures, and continues to subsume the resistance of emergent or minority positions to apparently dominant formations. This cannot be the case if one recognizes that locally emergent economic, sexual, and racial groups are continually resisting and contesting the homogenizing and totalizing tendencies of these so-called dominant discursive formations. For example, an interpretation of Indian history guided by the concept of a dominant colonialist discourse would represent India as having been thoroughly ruled and administered for a century and a half by British discourses, to the degree that Britain's rule can be said to have been aided by the extensive legal and administrative classification of India into forms of knowledge composed of census data, official reports, laws, histories, geographies, and encyclopedias. ${ }^{26}$ Considering these colonialist formations as comprehensive and statically dominant, however, ignores the ongoing and quite different Indian resistances that occurred throughout the British occupation, and places the power of colonialist discourse in the hands of the colonizer. In this regard it has been the aim of contemporary radical

\footnotetext{
${ }^{26}$ The work of the anthropologist Bernard S. Cohn is outstanding in analyzing the British discursive management of India. Cohn fastidiously documents the modalities through which the British discourses produced India as forms of knowledge: the survey, the census, the museum, legal codes, and so on. See Cohn, "The Command of Language and the Language of Command," in Subaltern Studies, vol. 4, ed. Ranajit Guha (Delhi: Oxford University Press, 1985); "The Census, Social Structure, and Objectification in South Asia," in An Anthropologist among the Historians and Other Essays (Delhi: Oxford University Press, 1987); and "Law and the Colonial State," in History and Power in the Study of Law, ed. Jane Collber and June Starr (Ithaca: Cornell University Press, 1989).
} 
historians, such as the Subaltern Studies Group, to reconstitute the histories of peasant and worker resistances, in order to displace traditional historical accounts and the official narrative through the articulation of these counternarratives. ${ }^{27}$

Moreover, discursively constructed positions of otherness are neither fixed nor continuous. Representations of difference and otherness are multivalent, signifying distinct meanings within particular social and historical contexts. That is, marks denoting differences in social class, race, culture, or gender may in one set of social relations be used to exclude and marginalize a social group, while in another they may be appropriated or rearticulated as marks of privilege or empowerment. For example, Stuart Hall has remarked that the designations black and coloured signify quite different things in the distinct contexts of England and the Caribbean. Hall observes that in the English system, organized around a binary dichotomy which reflects the colonizing order of "white/not-white," the terms black and coloured are more or less synonymous, whereas in the Caribbean system, where race is organized in an ascending spectrum of classifications, black and coloured denote different points on the scale rising toward the ultimate term, white. ${ }^{28}$ Likewise, we will see in Chapter 4 that the signifier Indianness as difference serves as a multivalent hinge between the British colonialist discourse that subordinated Indians and the Indian articulation of Indianness as identity that criticized, and distinguished itself from, that colonialist discourse.

Another example of this multivalence can be found in the representation of racial and ethnic otherness in the contemporary United States. ${ }^{29}$ Two predominant tropes figure racial difference in current discourses: "racial Others are different from the dominant majority," and the apparently opposite configuration "racial others are like the

\footnotetext{
27See Dipesh Chakrabarty, "Conditions for Knowledge of Working-Class Conditions," and Gyanendra Pandey, "Peasant Revolt and Indian Nationalism," both in Selected Subaltern Studies, ed. Ranajit Guha and Gayatri C. Spivak (New York: Oxford University Press, 1988).

28See Stuart Hall, "Signification, Representation, Ideology: Althusser and the PostStructuralist Debates," Critical Studies in Mass Communication 2, no. 2 (June 1985): 91-114.

${ }^{29}$ The construction of "race" in contemporary American society has changed significantly since the 1950 as the result of many factors, including the civil rights movements of the 1950s and 1960s. See Michael Omi and Howard Winant, Racial Formation in the United States: From the 1960s to the 1980s (London: Routledge, 1986), for an analysis of this changing construction of race.
} 
majority." Both strategies for objectifying otherness-the Other as incomprehensible and threatening, and the Other as familiar and controllable-can be used as the means of objectifying racial difference. Ironically, both models rely equally on a logic of complementarity in which racial difference is always defined in terms of a naturalized Anglo-Saxon majority or norm. These two tropes however, - the Other as different and the Other as same-are unstable representations, and can also be reappropriated by racial and ethnic minority groups. The reappropriation of these tropes is one means through which racial and ethnic minorities may challenge the existing cultural hegemony, rearticulating different versions of the same formations into social and legal arguments. For example, the Other as different has been one of the significant tropes in the discourse of civil rights (as in, "We have different histories in the United States and different degrees of access to opportunity"). Alternatively, assertions of likeness or sameness are crucial to arguments about equality ("We have different access, but we are entitled to the same opportunities"). At the same time, it is clear that the matter of racial equality has not been corrected by racial and ethnic minority groups' merely reclaiming the tropes about racial otherness, for these tropes are unstable and have been reappropriated and used differently by those who argue against civil rights policies ("Minorities have equal opportunity; they are already 'the same' enough"). This implies that, in terms of institutional change, although it is necessary to accomplish the wider inclusion of minorities and women in dominant formations, there are also serious limitations to the kinds of transformation this assimilating inclusion can bring; in addition to these measures, it becomes essential to recast and rethink the structures and narratives of institutions themselves in terms of a critique of the logic of sameness and difference.

In order to begin to account for and theorize the dynamics of intervention, resistance, and change within discursive formations, one may support the understanding that discourses are not closed monoliths by emphasizing the heterogeneity of both the means and the practices of representation. First, signs and objects coded as either dominant or emergent are multivalent; a sign that is in one social context part of an apparatus of exclusion may be appropriated and rearticulated as part of an enabling formation. Second, discursive formations are heterotopic, generated from different positions or 
spaces on the discursive terrain. Orientalism is irregularly composed of statements and restatements, contestations, and accommodations, generated from an incongruous series of writing positions; it simultaneously includes formations that may be identified as dominant as well as emergent, and challenging interventions may be articulated from a variety of uneven and unequal spaces on the terrain. In this sense, the theoretical problem facing cultural criticism is not how to fit slippage, instability, and multivalence into a conception of dominant ideology and counterideology or discourse and counterdiscourse. Rather, cultural critics might approach this question from the other direction: that is, that heterogeneities and ambivalences are givens in culture. These nonequivalences and noncorrespondences are not the objects to be reconciled or explained; they must constitute the beginning premise of any analysis.

Finally, cultural criticism that makes use of the logic of otherness must historicize and theorize its own methods and objects. This is to say that theories are produced, as are all narratives, in particular social contexts and by the particular tensions, contradictions, and pressures of that historical moment. In the final chapter I suggest that one way to explain the recuperation of orientalism by the intellectuals at Tel quel is to understand it as a response to their disappointment over the "failed" strikes of May 1968. French Maoism implied a judgment on the part of these progressive theorists of the late 1960s that revolution could never occur in France, and that nothing would be sacrificed if they turned their gaze toward a political utopia elsewhere. In the wake of what was judged to be a thwarted revolution, the romance with China's Cultural Revolution served as a means for some intellectuals to turn away from the still demanding struggles in France-struggles not limited to the rebuilding of a fragmented and disillusioned Left but, more important, arising from a growing racial and class stratification in France resulting from the postcolonial displacement of immigrants from North Africa, Indochina, and the Caribbean. In this sense my discussion of Kristeva, Barthes, and Tel quel in Chapter 5 serves as a cautionary illustration of the dangers of ahistorical literary theory, or theory that does not interrogate the circumstances of its own production and can therefore be appropriated by institutions or ideologies to justify the status quo. In this respect I wish to attach this book's discussion of heterogeneity clearly to a twofold critical project that 
responds to the specific context of the present. On the one hand, my discussion is conceived as an interruption of traditional orientalist and colonialist representations, and in this sense heterogeneity among categories of otherness is stressed in order to target the reductive and homogenizing aspects not only of orientalist stereotypes but also of the continued institutional production of binary theories about various social differences. On the other hand, the critique of binary conceptions of difference is also part of a discussion among scholars involved in the critical study of colonialism and cultural domination; it is aimed at reducing the explanatory power of the binary model of "the West and the Rest," and suggests that the prevalent model of nationbased politics may risk suppressing or precluding affiliation with positions inscribed by other valences of oppression. In this sense, this book describes heterogenous discursive terrains, not to contribute to a liberal pluralistic model of multiculturalism, but rather to emphasize that the relationships between Europe and colonized cultures are crossed by other interpellations and stratifications not reducible to the commonly held binary antagonism, and, most important, to underscore these overlapping and multiple inscriptions as moments of particular vulnerability in dominant discursive formations. By foregrounding heterogeneity I do not mean to obscure the fundamental difference of power between colonizers and colonizeds. Rather, I wish to open spaces that permit the articulation of other differences-themselves incongruous and nonequivalent-not only of nation and race but also of gender, class, region, and sexual preference. Thus, in understanding the logic of otherness as an apparatus that cannot but reinscribe a binary logic of domination and subordination, one must now question the continuing efficacy of using these terms in a critical analysis of power. For this reason, my ultimate aim is to challenge and resist the binary logic of otherness by historicizing the critical strategy of identifying otherness as a discursive mode of production itself. 